\title{
SOCI
}

(p-ISSN) 1829-5797

(e-ISSN) $2549-9475$

J URN AL I LM U - ILMU SOS IAL

Vol. 13, No.2, 2016

\section{Politik Pendidikan Indonesia dalam Membentuk Good Citizens Pada Era Reformasi}

\author{
DWI WIJAYANTI, MARZUKI \\ Universitas Negeri Yogyakarta \\ Email : dwi_wijayanti1106@yahoo.com,marzukiwafi@yahoo.co.id
}

\begin{abstract}
Abstrak
Penelitian ini bertujuan untuk: (1) mengetahui dan memahami PKn sebagai instrumen politik pendidikan dalam membentuk good citizens; (2) mengidentifikasi dan menganalisis muatan aspek civic knowledge, civic skill, dan civic disposition pada buku teks PKn era Reformasi. Jenis Penelitian deskriptif kualitatif yang dilaksanakan di Yogyakarta, Solo dan Jakarta. Subjek penelitian adalah Buku Sekolah Elektronik (BSE) yaitu: (1) Pendidikan Kewarganegaaraan untuk SMP Kelas VII karya A.T Sugeng Priyanto,dkk; (2) Pendidikan Pancasila dan Kewarganegaraan SMP/MTs Kelas VII karya Lukman Surya Saputra dan Wahyu Nugroho. Pengumpulan data menggunakan metode wawancara dan dokumentasi. Teknik analisis data mencakup unitization, sampling, recording, data reduction, analysis, dan inference. Hasil penelitian menunjukkan bahwa dalam buku PKn Kurikulum KTSP 2006 arah politik pendidikan adalah membentuk warga negara yang cerdas, terampil, dan berkarakter, sadar akan hak dan kewajiban, serta mampu berpartisipasi aktif dalam kehidupan bermasyarakat, berbangsa dan bernegara. Aspek pengetahuan (civic knowledge) dan keterampilan (civic skill) lebih dominan, sedangkan watak kewarganegaraan (civic disposition) kurang dikembangkan. Dalam Buku PKn Kurikulum 2013 arah politik pendidikan yaitu untuk mempersiapkan warga negara yang beriman, produktif, kreatif, inovatif, dan afektif serta mampu berkontribusi pada kehidupan bermasyarakat, berbangsa, bernegara, dan peradaban dunia. Aspek civic disposition lebih dominan terdiri dari sikap spiritual dan sosial, sedangkan aspek pengetahuan (civic knowledge) serta keterampilan (civic skill) kurang mengembangkan.
\end{abstract}

Kata Kunci : Politik Pendidikan, Buku teks PKn, Civic knowledge, Civic skill, Civic disposition, Good citizens.

\section{Abstract}

The objectives of the research are: (1) to know and understand Civic Education subject as educational politics instrument in building good citizens. (2) to identify and analyze the aspects of civic knowledge, civic skill, civic disposition in the text book of Civic Education in Reformation era.This research is a qualitative descriptive research with the content analysis conducted in Yogyakarta, Solo, and Jakarta. The subjects of the research is Buku Sekolah Elektronik (BSE): (1) Pendidikan Kewarganegaraan untuk SMP Kelas VII written by A.T. Sugeng Priyanto, etc; (2) Pendidikan Pancasila dan Kewarganegaraan SMP/MTs Kelas VII written by Lukman Surya Saputra \& Wahyu Nugroho. The data collection was conducted by interview and documentation method. Techniques of analyzing the data are unitization, sampling, recording, data reduction, analysis, and inference. The result of the research shows that the directional education politics in the Civic Education text book KTSP Curriculum 2006 is building good citizens including skilled, characteristic citizens, aware to the right and obligation also be able to participate actively in society, nation and state. The content of civic knowledge and civic skill are dominant, while civic disposition is less developed. the directional education politics in the Civic Education text book Curriculum 2013 is building a good citizens including faithful, productive, creative, innovative and effective and also can contribute to the existence of society, nation, state and world civilization. The content of civic disposition is more dominant and consist of spiritual and social aspect, whilw civic knowledge and civic skill are less developed.

Keywords : Educational politics, Civic education text book, Civic knowledge, Civic skill, Civic disposition, and Good citizens. 


\section{PENDAHULUAN}

Demokrasi merupakan suatu yang penting karena nilai-nilai yang terkandung di dalamnya sangat diperlukan sebagai acuan untuk menata kehidupan berbangsa dan bernegara yang lebih baik. Demokrasi adalah suatu learning process yang tidak dapat begitu saja meniru dari masyarakat lain (Zamroni, 2011, p.25). Karakter demokratis yang ada pada diri seseorang tidaklah tumbuh secara alami, melainkan hasil dari suatu rekayasa sosial, khususnya pendidikan. Oleh karena itu, perlu adanya pendidikan yang bersifat demokratis.

Pendidikan demokrasi dalam banyak hal identik dengan pendidikan kewarganegaraan (civic education). Perkembangan PKn di Indonesia mengalami berbagai macam perubahan baik dilihat dari struktur materi maupun tujuan dan metode pengajarannya. Sebelum tahun 1959 dikenal dengan nama Tata negara, Tata Hukum dan Ilmu Kewarganegaraan. Pada tahun 1959 keluar Dekrit Presiden yang banyak mengubah sistem ketatanegaraan saat itu. Setelah tahun 1959 PKn disebut Civics dengan "Civics Manusia Indonesia Baru" dan "Tujuh Bahan Pokok Indoktrinasi (TUBAPI)" sebagai buku sumber. Buku tersebut merupakan bentuk nyata dari politik pendidikan Indonesia yang dilakukan dengan cara indoktrinasi. Kemudian pada tahun 1962 istilah $\mathrm{Ci}$ vics diganti dengan Kewargaan Negara dengan tujuan membentuk manusia-manusia pembangunan yang berbudi pekerti luhur (Murdiono, 2012, p.41). Namun kenyataannya pada masa ini, Kewargaan Negara cenderung menekankan pada aspek sejarah, tata negara dan politik, sedangkan aspek moral belum dimunculkan.

Pada Tahun 1973 MPR menetapkan GBHN yang di dalamnya menginstruksikan adanya PMP disemua jenjang sekolah. Tahun 1983 sidang MPR berhasil menetapkan GBHN baru yang di dalamnya menginstruksikan bahwa Pendidikan Pancasila di dalamnya termasuk materi PMP, Pendidikan P4, dan Pendidikan Sejarah Perjuangan Bangsa (PSPB). Pada tahun 1994 nama PMP berubah menjadi Pendidikan Pancasila dan Kewarganegaraan (PPKn),
(Murdiono, 2012, p.42) Materi yang terkandung dalam PPKn jauh berbeda dengan materi yang ada dalam PMP. Hal ini terjadi karena materi dalam PMP memuat tentang butir-butir P4 yang merupakan alat indoktrinasi pemerintah Orde Baru (Orba) untuk mempertahankan kekuasaannya.

Pada masa Reformasi tahun 2000, Kurikulum Berbasis Kompetensi (KBK) merubah PPKn menjadi Pendidikan Kewarganegaraan (PKn) yang bertujuan membentuk warga negara yang cerdas, terampil, dan berkarakter yang setia kepada bangsa dan negara Indonesia dengan merefleksikan dirinya dalam kebiasaan berpikir, bertindak sesuai dengan amanat Pancasila dan UUD 1945. Dari tujuan ini kemudian dikembangkan paradigma baru pendidikan kewarganegaraan yaitu dengan menekankan pada aspek pengetahuan (knowledge), keterampilan (skill) dan karakter (disposition) yang berupa watak kewarganegaraan. Berbagai perubahan yang terjadi tersebut menujukkan bahwa PKn belum memiliki dasar keilmuan yang jelas. Tidak ada buku khusus yang diterbitkan oleh pemerintah, yang dijadikan buku wajib dalam pembelajaran PKn. Buku-buku teks yang ada merupakan buku teks terbitan dari pihak swasta yang dinilai terlebih dahulu oleh (Badan Standar Nasional Pendidikan) BSNP.

Pada masa ini tidak ada buku wajib dari Pemerintah yang dijadikan sumber bacaan utama. Hal ini dikarenakan adanya sistem desentralisasi pendidikan. Untuk menjamin bahwa para siswa di seluruh Indonesia dapat memperoleh buku teks yang bermutu, Pemerintah Republik Indonesia telah melakukan banyak langkah yang di antaranya adalah pengembangan naskah dan pengendalian mutu buku. Peraturan Pemerintah Nomor 19 Tahun 2005 tentang Standar Nasional Pendidikan, khususnya dalam hal perbukuan, mensyaratkan bahwa buku-buku teks yang digunakan oleh siswa harus terlebih dahulu dinilai oleh Badan Standardisasi Nasional Pendidikan (BSNP). Sejak itu Pemerintah Republik Indonesia, dalam hal ini Departemen Pendidikan Nasional, menjalankan program penilaian buku teks de- 
ngan maksud mengendalikan mutu bukubuku teks yang akan dipergunakan oleh para pelajar Indonesia.

Selanjutnya dalam Peraturan Pemerintah No.32 tahun 2013 tentang Perubahan atas Peraturan Pemerintah No.19 tahun 2005 tentang Standar Nasional Pendidikan Pasal 43 ayat 5 dan 5 a, disebutkan bahwa dalam hal pengadaan buku teks pelajaran dilakukan Pemerintah. Menteri menetapkan buku tersebut sebagai sumber utama belajar dan pembelajaran setelah ditelaah dan/atau dinilai oleh BSNP atau tim yang dibentuk oleh menteri. Selain menstandarrisasi mutu dan mengupayakan keterjangkauan harga, pemerintah juga mengupayakan kemudahan akses terhadap buku-buku tersebut. Caranya adalah dengan menyediakan buku-buku yang hak ciptanya telah dimiliki Pemerintah di laman internet. Buku-buku tersebut diberi nama Buku Sekolah Elektronik (BSE). Meskipun telah mengupayakan keterjangkauan harga.

Desentralisasi pendidikan memang memiliki makna yang signifikan bagi pengembangan demokrasi, namun pendidikan yang ada di Indonesia lebih banyak didominasi oleh keputusan yang bersifat top-down daripada bottom-up. Begitu pula dengan penulisan buku pelajaran PKn. Dalam pelaksanaannya, PKn sangat rentan terhadap bias politik praktis penguasa sehigga ia cenderung lebih merupakan instrumen penguasa daripada sebagai wahana pembangunan watak bangsa berdasarkan konstitusi (Sapriya, 2007, p.25). Karena PKn merupakan mata pelajaran yang mudah mendapat intertvensi dari rezim penguasa, maka muatan isi buku PKn juga kerap merefleksikan kepentingan dari penguasa itu sendiri sehingga tujuan PKn untuk membentuk karakter siswa yang sesuai dengan Pancasila dan UUD 1945 belum berhasil. Kegagalan itu bersumber dari tiga hal. Pertama, secara substantif PKn tidak secara terencana dan terarah mencakup materi dan pembahasan yang lebih terfokus pada pendidikan demokrasi dan kewarganegaraan. Materi-materi yang ada pada umumnya terpusat pada pembahasan yang bersifat idealistik, legalistik dan normatif. Kedua, kalaupun ma- teri-materi yang ada pada dasarnya potensial bagi pendidikan demokrasi dan PKn, potensi itu tidak berkembang karena pendekatan dalam pembelajarannya bersifat indoktrinatif, regimentatif, monologis dan tidak partisipatif. Ketiga, subjek itu lebih teoritis daripada praktis. Akibatnya bisa dipahami bahwa sekolah gagal membawa peserta didik untuk mengalami demokrasi (Tilaar, 2002, p.243-244).

Berdasarkan latar belakang di tersebut, maka rumusan permasalahan yang dikemukakan adalah: (1) bagaimana mata pelajaran PKn menjadi instrumen politik pendidikan dalam membentuk good citizens?; (2) bagaimana muatan aspek civic knowledge, civic skill dan civic disposition pada buku teks PKn era Reformasi?

\section{METODE \\ Jenis Penelitian}

Penelitian ini dikategorikan sebagai penelitian deskriptif kualitatif. Pada penelitian deskriptif kualitatif, para peneliti berusaha menggambarkan kegiatan penelitian yang dilakukan pada objek tertentu secara jelas dan sistematis, (Sukardi, 2008, p.14).

\section{Waktu dan Tempat Penelitian}

Penelitian ini dilaksanakan dengan teknik content analysis dan wawancara. Content analysis merupakan penelitian kepustakaan sehingga tidak terikat oleh tempat, sedangkan wawancara dilakukan sesuai dengan domisili narasumber yaitu di Yogyakarta, Solo dan Jakarta. Waktu penelitian pada bulan Februari-Mei 2014.

\section{Subjek Penelitian}

Subjek penelitian ini adalah buku Pendidikan Kewarganegaraan untuk SMP kelas VII edisi 4, yang ditulis oleh A.T Sugeng Priyanto, Djaenudin Harun, Anang Priyanto, Cholisin, dan Muchson A.R, dan buku Pendidikan Pancasila dan Kewargangaraan SMP/MTs Kelas VII yang ditulis oleh Lukman Surya Saputra dan Wahyu Nugroho. Peneliti juga melakukan pengambilan data melalui wawancara. Penentuan subjek wawancara mengunakan teknik pur- 
posive sample. Adapun kriteria yang ditentukan dalam penelitian ini adalah: (1) seseorang yang terlibat dalam pembuatan kebijakan kurikulum PKn untuk tingkat Pendidikan Dasar dan Menengah serta memahami betul PKn pada jenjang tersebut; (2) orang memiliki keahlian dan spesialisasi di bidang PKn; (3) orang yang menulis buku teks PKn; (4) orang yang menelaah buku teks PPKn kurikulum 2013. Berdasarkan kriteria tersebut maka yang menjadi subjek wawancara adalah: Prof. Dr. Udin S. Winataputera, Prof. Dr. Sapriya, Dr. Sunarso, M.Si, Cholisin, M.Si. dan Muchson A.R, M.Pd.

\section{Teknik dan Prosedur Pengumpulan Data}

Teknik pengumpulan data yang digunakan dalam penelitian ini adalah dokumentasi dan wawancara. Dokumentasi dilakukan dengan cara mengkaji dan mempelajari isi dari buku-buku pelajaran PKn tingkat SMP kelas 1 kurikulum KTSP 2006 dan kurikulum 2013, yang didukung dengan dokumen terkait seperti Undang-Undang Dasar 1945, Undang-Undang No.20 Tahun 2003 Sisdiknas, Permendiknas, Permendikbud, dll. Dari dokumen tersebut dilakukan kajian terhadap isinya sehingga diperoleh pemahaman mengenai politik pendidikan yang dilakukan oleh negara Indonesia dalam membentuk good citizens. Wawancara dalam penelitian ini adalah wawancara tak terstruktur dengan menggunakan pedoman wawancara yang hanya memuat garis besar, yang akan ditanyakan terhadap responden, kemudian pertanyaan tersebut dikembangkan sendiri oleh peneliti pada saat wawancara.

Instrumen pengumpulan data ini adalah peneliti sendiri. Dalam penelitian kualitatif yang menjadi instrumen utama adalah peneliti sendiri, (Sugiyono, 2007, p.307). Selain itu terdapat pula pedoman wawancara tidak terstruktur yang dipergunakan untuk mengumpulkan data guna mendukung data dokumentasi yang telah ada serta alat dokumentasi antara lain kamera, alat perekam suara, alat tulis dll.

Teknik pemeriksaan keabsahan data dilakukan dengan langkah-langkah sebagai berikut: (1) Cross check. Teknik Cross check dilakukan dengan membandingkan informa- si yang diperoleh dari teknik wawancara dan membuktikannya melalui dokumentasi. Selain itu jugadilakukan dengan cara membandingkan informasi dari satu orang dengan informasi dari orang lain; (2) Analisis kasus negatif, yaitu peneliti mencari data yang berbeda atau bertentangan dengan data yang telah ditemukan. Bila tidak ada data yang berbeda atau bertentangan dengan data yang ditemukan berarti data yang ditemukan sudah dapat dipercaya. Namun apabila ada data yang bertentangan maka peneliti akan menganalisis ulang hasil penelitiannya; (3) Menggunakan bahan referensi yaitu bukti pendukung dari data-data yang diperoleh peneliti berupa rangkuman hasil wawancara, catatan lapangan dari hasil observasi, dan dokumen terkait seperti kurikulum pendidikan, catatan kejadian, dan lainnya.

\section{Teknk Analisis Data}

Teknik Analisis data dilakukan dengan cara teknik analisis isi (content analysis) yaitu mencakup upaya-upaya klasifikasi lambang-lambang yang dipakai dalam komunikasi, menggunakan kriteria dalam klasifikasi, dan menggunakan analisis tertentu dalam membuat prediksi (Burhan, 2008, p.84-85). Penelitian analisis isi meliputi: (1) unitization, (2) sampling, (3) recording, (4) data reduction, (5) analysis dan (7) inference (kesimpulan), (Krippendorff, 1981, p.54).

Tahap pertama unitization, pada bagian ini akan dipaparkan secara rinci beberapa jenis unit yang akan dianalisis. Unit tersebut adalah paragraf dalam buku teks PKn yang memuat tentang civic knowledge, civic skill dan civic disposition.

Tahap kedua sampling, yaitu pemilihan buku teks PKn yang akan di analisis. Buku yang dipilih berupa Buku Sekolah Elektronik PKn tingkat SMP kelas 1 pada kurikulum KTSP 2006 dan kurikulum 2013. Buku tersebut merupakan buku paket yang hak ciptanya dibeli oleh Pemerintah.

Tahap ketiga recording atau pencatatan. Pencatatan untuk mengetahui perbandingan pesan (message) dokumen yang sama pada waktu yang berbeda. Dalam hal ini analisis 
dapat membuat kesimpulan mengenai kecenderungan isi buku terhadap pembentukan karakter good citizens dan melihat bagaimana sistem politik mempengaruhinya.

Tahap keempat reduction.Tahap ini merupakan proses pemilihan, pemusatan perhatian, pengabstraksian dan pentransformasian data kasar yang diperoleh selama penelitian. Fungsinya untuk menajamkan, menggolongkan, mengarahkan, membuang yang tidak perlu, dan mengorganisasi sehingga interpretasi bisa ditarik.

Tahap kelima analysis. Peneliti membuat rumusan proporsi yang terkait dengan prinsip logika berdasarkan teori-teori dan pengetahuan yang ada, lalu mengangkatnya menjadi temuan penelitian, kemudian dilanjutkan dengan mengkaji dan menganalisis secara berulang-ulang terhadap data yang ada. Analisis ini juga dilakukan terhadap data yang diperoleh melalui wawancara untuk kemudian dicrosscheck dengan dokumen yang diperoleh.

Tahap terakhir inference atau penarikan kesimpulan. Penarikan kesimpulan dengan berangkat dari rumusan masalah atau tujuan penelitian kemudian senantiasa diperiksa kebenarannya untuk menjamin keabsahannya. Pengambilan kesimpulan dilakukan dengan cara berfikir induktif yaitu dari hal yang khusus diarahkan kepada hal-hal yang umum untuk mengetahui jawaban dari permasalahan dalam penelitian ini.

\section{HASIL DAN PEMBAHASAN \\ Politik Pendidikan dalam Membentuk Good Citizens melalui PKn.}

Politik pendidikan di Indonesia tertuang dalam pembukaan UUD 1945 Alinea IV yang berbunyi "mencerdaskan kehidupan bangsa" hal ini kemudian dijabarkan lagi ke dalam Pasal 31 Ayat (1) yang berbunyi "Setiap warga negara berhak mendapat pendidikan." dan Ayat (3) yang berbunyi "Pemerintah mengusahakan dan menyelenggarakan satu sistem pendidikan nasional, yang meningkatkan keimanan dan ketakwaan serta akhlak mulia dalam rangka mencerdaskan kehidupan bangsa, yang diatur dengan undang-undang."
Pada era Reformasi, penjabaran Pasal 31 Ayat (3) UUD 1945 tertuang dalam UndangUndang No.20 tahun 2003 tentang Sistem Pendidikan Nasional, Pasal 1 Ayat (2) yang berbunyi "Pendidikan nasional adalah pendidikan berdasarkan Pancasila dan Undang-Undang Dasar Negara Republik Indonesia Tahun 1945 yang berakar pada nilai-nilai agama, kebudayaan nasional Indonesia dan tanggap terhadap tuntutan zaman." Lalu dipertegas lagi Pasal 3 berikut ini:

Pendidikan nasional berfungsi mengembangkan kemampuan dan membentuk watak serta peradaban bangsa yang bermartabat dalam rangka mencerdaskan kehidupan bangsa, bertujuan untuk berkembangnya potensi peserta didik, agar menjadi manusia yang beriman dan bertakwa kepada Tuhan Yang Maha Esa, berakhlak mulia, sehat, berilmu, cakap, kreatif, mandiri, dan menjadi warga negara yang demokratis serta bertanggung jawab.

Demi mencapai tujuan pendidikan nasional tersebut maka terdapat tiga mata pelajaran yang wajib diajarkan mulai dari pendidikan dasar, menengah hingga pendidikan tinggi. Mata pelajaran tersebut adalah Pendidikan Agama, Pendidikan Kewarganegaraan dan Bahasa. Ketentuan ini tercantum dalam pasal 37 Undang-Undang No.20 tahun 2003 tentang Sistem Pendidikan Nasional, dengan penjelasan bahwa:

Pendidikan agama dimaksudkan untuk membentuk peserta didik menjadi manusia yang beriman dan bertakwa kepada Tuhan Yang Maha Esa serta berakhlak mulia. Pendidikan kewarganegaraan dimaksudkan untuk membentuk peserta didik menjadi manusia yang memiliki rasa kebangsaan dan cinta tanah air. Bahan kajian bahasa mencakup bahasa Indonesia, bahasa daerah, dan bahasa asing dengan pertimbangan bahwa: (1) Bahasa Indonesia merupakan bahasa nasional; (2) Bahasa daerah merupakan bahasa ibu peserta didik; dan (3) Bahasa asing terutama bahasa Inggris merupakan bahasa internasional yang sangat penting kegunaannya dalam pergaulan global.

Dari uraian tersebut jelas bahwa PKn memiliki peran yang sangat penting dalam politik pendidikan di Indonesia guna mencapai tujuan pendidikan nasional yaitu membentuk 
peserta didik menjadi manusia yang memiliki rasa kebangsaan dan cinta tanah air, dan menjadi warga negara yang demokratis serta bertanggung jawab. Hal ini membuat mata pelajaran PKn mudah disisipi nilai-nilai yang bersifat politis. Penyisipan tersebut dilakukan melalui buku teks pelajaran. Dari sudut pandang metodologis atau sosiologis, buku-buku yang ditulis secara mekanis, betapa pun baiknya tetap tidak dapat menghapuskan "dosa aslinya" sebagai "alat penyetor kata-kata" kepada peserta didik (Freire, 2007, p.36). Dengan menggunakan kata-kata yang bermuatan ideologis, buku teks pelajaran justru semakin memperkuat budaya bisu dan buku semacam itu tidak dapat dijadikan alat transformatif sosial yang sesungguhnya.

Di Indonesia, buku teks selalu mengikuti perkembangan kurikulum yang ada mulai dari Orde lama, Orde Baru hingga era Reformasi. Era Reformasi mengalami empat kali perubahan kurikulum yaitu Suplemen 1999, Kurikulum Berbasis Kompetensi (KBK) tahun 2004, Kurikulum Tingkat Satuan Pendidikan (KTSP) tahun 2006 dan kurikulum 2013. Pada kurikulum 1999 hingga KBK 2004, berdasarkan Keputusan Direktur Jenderal Pendidikan Dasar dan Menengah No.262/C/ Kep/R.1992 yang dimaksud dengan buku teks adalah buku pelajaran pokok atau yang sering disebut dengan buku wajib, merupakan buku acuan utama yang dipergunakan oleh siswa dan guru dalam kegiatan belajar mengajar. Di dalam Permendiknas No.11 tahun 2005 tentang Buku Teks Pelajaran dan Permendiknas No.2 tahun 2008 tentang Buku juga tertulis bahwa "Buku teks pelajaran adalah buku acuan wajib untuk digunakan di sekolah". Hal ini berarti buku teks pelajaran memiliki peran yang sangat penting dalam proses pendidikan d Indonesia, sehingga melalui buku teks inilah sering disisipkan nilai-nilai ingin diajarkan kepada siswa. Berikut ini uraian lebih lanjut mengenai politik pendidikan melalui buku PKn era Reformasi:

\section{Buku PKn Kurikulum KTSP 2006}

Kurikulum KTSP tahun 2006 merupakan revisi terhadap kurikulum KBK 2004 yang notabeneterkesandipaksakan pemberlakuannya dengan waktu yang relatif singkat. Pada kurikulum 2004, Indonesia mulai mengadopsi muatan Civic Education di Amerika yang tediri dari Civic Knowledge, Civic Skill dan Civic Disposition. Adopsi dilakukan hanya dalam rangka luar saja tetapi tidak pada substansi, hal ini dikarenakan Indonesia memiliki ideologi dan sistem pemerintahan yang berbeda, sehingga nilai-nilai kewarganegaraan yang ditanamkan kepada warga negara di Amerika tentu berbeda dengan Indonesia. Hal yang sama juga dikemukakan oleh Udin S.Winataputera yaitu:

Kurikulum PKn di Indonesia mengacu pada Civic di Amerika, itu tidak betul. Bukan mengacu tapi menggunakan kerangka berfikirnya, Kurikulum PKn di Indonesia mengacu tujuan pendidikan nasional. Yang kita adopt adalah cara berpikirnya, jadi desain kurikulumnya, yaitu bahwa pkn harus mencakup civic knowledge, civic skill dan disposition. Sebenarnya itu mirip dengan sikap, pengetahuan dan keterampilan juga, (Hasil wawancara pada hari Minggu, 27 April 2014).

Muatan ketiga aspek Civic Knowledge, Civic Skill dan Civic Disposition tetap mengenai Pancasila dan UUD 1945. Hal ini sesuai dengan fungsi mata pelajaran PKn sebagai wahana untuk membentuk warga negara cerdas, terampil, dan berkarakter yang setia kepada bangsa dan negara Indonesia dengan merefleksikan dirinya dalam kebiasaan berpikir dan bertidak sesuai dengan amanat Pancasila dan UUD 1945.

Keseluruhan materi tersebut membuat PKn Kurikulum KBK sudah mulai nampak akar keilmuannya, namun muatan moral justru sedikit sekali. Lebih lanjut Sunarso mengatakan bahwa:

Saya melihat kurikulum 2004, 2006 KTSP itu memang dari sudut pandang keilmuannya semakin jelas, akar keilmuannya jelas nampak, Cuma kalo dikatakan moralnya sedikit, iya benar. Sesungguhnya itu ada 8 tema ya dan Pancasila hanya sebagai tema ke-7 kalau tidak salah, (Hasil wawancara pada hari Senin, 12 Mei 2014).

Materi dalam buku teks PKn Kelas VII Kurikulum KTSP 2006 ini terdiri dari: Pertama, norma hukum dan peraturan. materi ini bertu- 
juan untuk agar siswa dapat bertindak sebagai warga negara yang baik, yaitu warga negara yang sadar akan hukum; Kedua, makna proklamasi kemerdekaan dan konstitusi pertama. Melalui materi ini, diharapkan siswa akan mengerti dan memahami arti rela berkorban dalam membela tanah air, dan lebih menghargai kemerdekaan negara Indonesia dengan caracara yang positif serta menjadi warga negara yang berjiwa nasionalis; Ketiga perlindungan dan penegakan hak asasi manusia (HAM). Materi ini memiliki porsi yang lebih banyak dari pada BAB I dan II. melalui materi ini, diharapkan siswa dapat menjadi warga Negara yang baik, yaitu warga Negara yang sadar akan hak dan kewajibannya, menjunjung tinggi harkat dan martabat sebagai manusia, serta peduli/ turut berpartisipasi terhadap perlindungan dan penegakan HAM; Keempat, kemerdekaan mengemukakan pendapat. karakter yang ditanamkan kepada siswa adalah karakter warga negara yang berjiwa pemberani, kritis dan turut berpartisipasi aktif demi pencapaian tujuan nasional, namun tetap berdasarkan pada peraturan perundang-undangan yang berlaku.

Secara keseluruhan, muatan PKn dalam kurikulum KBK maupun kurikulum KSTP, keduanya tidak jauh berbeda. kurikulum KSTP merupakan penyempurnaan dari kurikulum KBK. Politik pendidikan pada masa ini lebih arahkan kepada pembentukan warga negara yang demokratis dan bertangung jawab sebagaimana tercantum dalam UU No.20 tahun 2003 tentang Sisdiknas.

\section{Buku PPKn Kurikulum 2013}

Buku kurikulum 2013 ini berbeda dengan buku teks pada kurikulum 1999, 2004 dan 2006. Pada kurikulum sebelumnya materi pokok (1999) dan KD (2004 dan 2006) dipelajari secara runtut melalui materi yang terpisah di setiap babnya, sedangkan dalam kurikulum 2013 dalam 1 bab terdapat campuran KD 1 hingga KD 4. KD I merupakan sikap spiritual, KD 2 adalah sikap social, KD 3 adalah pengetahuan dan KD keterampilan.

Ranah sikap meliputi sikap spiritual dan sikap sosial. Sikap spiritual di pelajari pertama kali karena negara ingin membentuk karakter warga negara yang religius, mampu bersikap dan bertindak senantiasa berdasarkan ajaran agama yang dianut. Ranah kedua yaitu sikap sosial. Menekankan manusia sebagai makhluk sosial yang selalu beriteraksi dengan manusia lain sehingga diperlukan sikap sosial. Sikap sosial dibentuk melalui pemahaman terhadap materi yang bersifat pengembangan aspek kognitif. Ranah keterampilan merupakan ranah di mana siswa mempraktekan materi yang telah dipelajari melalui pengerjaan tugas-tugas dan latihan soal. Buku teks pelajaran PPKn ini terdiri dari 9 bab sebagai berikut: (1) Beriman dan Bertakwa kepada Tuhan Yang Maha Esa: Watak warga negara yang diharapkan adalah warga negara yang religius yaitu warga negara yang memiliki kesadaran untuk berkeTuhanan YME, senantiasa beriman dan bertakwa sehingga terbentuk warga negara yang berakhlak mulia guna menuju masyarakat yang adil dan makmur; (2) Berkomitmen terhadap Panca sila sebagai Dasar Negara: Watak warga negara yang dibentuk adalah warga negara yang memiliki jiwa nasionalisme, cinta tanah air serta rela berkorban demi bangsa dan negara; (3) Menumbuhkan Kesadaran Berkonstitusi: Watak warga negara yang dibentuk adalah warga negara yang memiliki kesadaran berkonstitusi yaitu dapat bersikap dan bertindak sesuai UUD 1945; (4) Menumbuhkan Kesadaran dan Keterikatan terhadap Norma: membentuk karakter warga negara yang taat akan hukum, yaitu bersikap dan bertindak sesuai dengan hukum yang berlaku; (5) Memaknai Nilai Kesejarahan Negara Kesatuan Republik Indonesia: membentuk karakter warga negara yang bangga berbangsa dan bertanah air Indonesia, memiliki kemauan untuk melindungi dan mempertahankan tanah air Indonesia melalui semangat rela berkorban, rasa memiliki serta semangat nasionalisme; (6) Pentingnya Daerah dalam Bingkai NKRI: Watak warga negara yang diharapkan adalah warga negara yang memiliki rasa cinta tanah air, mampu membela negara, serta kesadaran untuk ikut menyukseskan pelaksanaan otonomi daerah; (7) Memelihara Semangat Persatuan Indonesia: Watak war- 
ga negara yang dibentuk adalah warga negara yang memiliki rasa nasionalisme, rasa bangga terdahap tanah air, toleransi terhadap perbedaan, serta menjunjung tinggi hak asasi manusia; dan (8) Bertoleransi dalam Keberagaman: membentuk karakter warga negara yang memiliki rasa cinta tanah air, nasionalisme, bangga terhadap budaya sendiri, menjunjung tinggi harkat, derajat dan martabat manusia serta bertoleransi dalam perbedaan.

Secara menyeluruh muatan buku teks PPKn ini lebih banyak muatan moral (civic disposition) dan keterampilan (civic skill), sedangkan aspek pegetahuan (civic knowledge) kurang dikembangkan. Hal yang sama dikemukakan pula oleh Muchson yaitu "buku teks PKn kurikulum 2013 diakui memang memiliki muatan keilmuan kewarganegaraan yang kurang, justru penekananya lebih pada kompetensi spiritual dan sosial, dan itu diakui oleh penulis buku", (Hasil wawancara pada hari Kamis, 8 Mei 2013). Pembentukan warga negara lebih banyak ditekankan pada ranah sikap sikap spiritual dan sosial di mana warga negara yang ingin di bentuk adalah warga negara yang religius (beriman), cinta tanah air, sadar hukum serta mampu berkontribusi pada kehidupan bermasyarakat, berbangsa, bernegara, dan peradaban dunia.

Pada kurikulum 2013, kebijakan pendidikan dapat dikatakan kembali kearah sentralisasi, di mana semua perangkat kurikulum termasuk RPP sudah dipersiapkan dari pusat dengan tujuan pembelajaran akan lebih mudah dan seragam. Guru hanya tinggal melaksanakan saja. Bagi guru yang kreatif maka hal ini dapat dimanfaatkan untuk pengembangan proses pembelajaran lebih lanjut, namun untuk guru yang tidak kreatif maka segala perangkat kurikulum dari pusat lebih dijadikan sebagai kitab suci dan mereka hanya terima jadi saja.

Dalam penelitian ini, terdapat temuan bahwa ada ketidaksesuaian KD di dalam silabus, buku teks pelajaran dan Permendikbud No.68 tahun 2013 tentang Kerangka Dasar dan Struktur Kurikulum Sekolah Menengah Pertama/Madrasah Tsanawiyah, yang dapat dicermati sebagai berikut:
Perbedaan yang pertama adalah penggunaan istilah "Gender" pada Permendiknas Permendikbud No.68/2013 tentang Kerangka Dasar dan Struktur Kurikulum SMP/MTs dengan istilah "Jenis kelamin" pada buku teks PPKn yang terletak pada KD 2.3; 4.6 ; 4.7 .1 dan 4.7.2. Kedua istilah tersebut memiliki arti yang sangat berbeda. Jenis kelamin terdiri dari Pria dan Wanita yang merujuk pada sifat jasmani (secara bologis/ sejak lahir) dan tidak dapat berubah. Sedangkan gender lebih pada peran dan kedudukan yang melekat pada jasmani Pria dan Wanita dan bisa berubah sesuai dengan kondisi sosial individu.

Perbedaan kedua adalah urutan KD. Pada Permendiknas Permendikbud No.68/2003 tentang Kerangka Dasar dan Struktur Kurikulum SMP/MTs "Memahami karakteristik daerah tempat tinggalnya dalam kerangka NKRI" terletak pada KD 3.5 dan materi "Memahami pengertian dan makna Bhinneka Tunggal Ika" terletak pada KD 3.7. Sedangkan pada buku teks PPKn materi "Memahami karakteristik daerah tempat tinggalnya dalam kerangka NKRI" berada pada KD 3.7 dan materi "Memahami pengertian dan makna Bhinneka Tunggal Ika" terletak pada KD 3.5. Perbedaan ini memang tidak teralu signifikan tetapi akan berpengaruh terhadap proses belajar anak karena pada dasarnya KD dibuat berdasarkan tingkat penalaran siswa, di mana KD yang tinggi dapat dicapai setelah siswa mampu mempelajari KD yang lebih rendah.

Perbedaan ketiga adalah muatan KD dalam KI 4. Pada Permendiknas Permendikbud No.68/2003 tentang Kerangka Dasar dan Struktur Kurikulum SMP/MTs, KI 4 dijabarkan dalam 8 KD sedangkan dalam buku teks hanya 6 saja (KD 4.7.1 sama dengan KD 4.7.2). Dengan demikian maka materi tentang "bentuk partisipasi kewarganegaraan yang mencerminkan komitmen terhadap keutuhan nasional" belum ada dalam buku teks tersebut. Padahal secara substansi, materi ini penting diajarkan agar terbentuk karakter warga negara yang tidak hanya religius, tidak hanya cerdas tetapi juga mampu berpartisipasi dalam kehidupan berbangsa dan bernegara serta memiliki karakter 
cinta tanah air demi mewujudkan keutuhan NKRI.

\section{Muatan Aspek Civic Knowlegde, Civic Skill dan Civic Disposition pada Buku Teks PKn Buku PKn Kurikulum KTSP 2006}

Kurikulum Tingkat Satuan Pendidikan (KTSP) merupakan salah satu upaya pemerintah untuk mencapai keunggulan masyarakat bangsa dalam penguasaan ilmu dan teknologi. Hal tersebut diharapkan dapat dijadikan landasan dalam pengembangan pendidikan di Indonesia yang berkualitas dan berkelanjutan, baik secara makro, meso maupun mikro. Kerangka makro erat kaitannya dengan upaya politik yang yaitu desentralisasi kewenangan dari pemerintah pusat ke daerah, sedangkan aspek mikronya melibatkan seluruh sektor dan lembaga pendidikan yang paling bawah, tetapi terdepan dalam pelaksanaannya yaitu sekolah.

Secara keseluruhan, muatan buku PKn kurikulum KTSP ini tidak jauh berbeda dengan buku PKn kurikulum KBK, yaitu lebih banyak memuat aspek kognitif. Perasaan moral (moral feeling) yang meliputi pentingnya norma, suasana kebatinan konstitusi UUD 1945, menghargai harkat dan martabat manusia, serta menghargai kemerdekaan mengemukakan pendapat secara bebas dan bertangung jawab. Tindakan moral (moral action) meliputi penerapan norma hukum dan peraturan dalam kehidupan nyata, melaksanakan konstitusi sebagai dasar hukum negara, turut serta dalam upaya perlindungan dan penegakan HAM, serta berpartisipasi dalam mengemukakan pendapat secara bebas dan bertanggung jawab.

Dalam buku teks PKn SMP kurikulum 2006 tersebut dapat dilihat bahwa muatan $c i-$ vic knowledge sebesar $60 \%$, civic skill dan civic disposition masing-masing $20 \%$. Hal ini menunjukkan bahwa aspek kognitif lebih diutamakan. Pembentukan siswa menjadi warga negara yang baik tidak hanya ditentukan oleh aspek kognitif saja, melainkan juga perlu adanya keterampilaan yang kemudian akan menjadi karakter pada siswa.

Warga negara yang baik adalah warga negara yang memiliki karakter yang memiliki pengetahuan moral (moral knowing), perasaan moral (moral feeling), dan perilaku moral ( $\mathrm{mo}$ ral behaviour) (Lickona, 1991, p.85). Dalam hal ini pengetahuan moral (moral knowing) meliputi pengetahuan terhadap norma hukum dan peraturan, makna proklamasi kemerdekaan, HAM dan kemerdekaan mengemukakan pendapat.

Sebagaimana tercantum dalam Permendiknas Republik Indonesia No.22 tahun 2006 tentang Standar Isi disebutkan bahwa tujuan PKn adalah untuk membentuk warga negara berpikir secara kritis, rasional, dan kreatif dalam menanggapi isu kewarganegaraan, berpartisipasi secara aktif dan bertanggung jawab, bertindak secara cerdas dalam kegiatan bermasyarakat, berbangsa, dan bernegara serta aktif dalam pencaturan global. Lebih lanjut/ Cholisin menyatakan bahwa:

Kurikulum 2006 itu mengukur warga negara yang baik adalah warga negara yang demokratis, mampu berfikir secara logis, kritis, mampu berpartisipasi, warga negara yang pada dasarnya memiliki sikap positif teradap nilainilai demokrasi, dan juga mampu berinteraksi dan berkomunikasi dengang bangsa-bangsa yang lain, (Hasil wawancara pada hari Rabu, 14 Mei 2014).

Tujuan dari civic education adalah partisipasi yang bermutu dan bertanggung jawab dalam kehidupan politik dan masyarakat baik di tingkat lokal, negara bagian dan nasional (Branson, 1999, p.7).. Hal ini menjukkan bahwa salah satu pemahan dari good citizens adalah warga negara yang demokratis. Istilah good citizens merujuk kepada warga negara tipe transformative citizenship, yaitu warga negara yang mengambil tindakan untuk mengaktualisasikan nilai-nilai dan prinsip-prinsip moral melampaui orang-orang dengan otoritas konvensional,(warga negara postkonvensional) (Banks, 2008, p.137).

Pengetahuan yang diajarkan kepada siswa, diterapkan guna mengasah keterampilan mereka dalam kehidupan riil. Apabila siswa sudah memiliki keterampilan kewarganegaraan maka diharapkan akan terbentuk karakter kewarganegaraan, yaitu mereka menjadi siswa 
yang tidak menguasai materi pelajaran, tetapi juga mampu mengembangkan pola berpikir kritis, mampu mengambil keputusan dan tindakan dalam usaha berpartisipasi mencapai tujuan nasional. Oleh karena itu seharusnya muatan ketiga aspek tersebut dapat berikan secara seimbang agar warga negara yang baik dapat terbentuk.

\section{Buku PPKn Kurikulum 2013}

Muatan meteri buku teks kurikulum 2013 ini jauh berbeda dengan muatan buku teks kurikulum suplemen 1999. Jika pada kurikulum 1999 hanya menekankan pada aspek moral, kurikulum 2004 dan 2006 menekankan pada civic knowledge, civic skill dan civic disposition, maka pada kurikulum 2013 ini menekankan pada ranah sikap terlebih dahulu, baik sikap spiritual maupun sikap sosial lalu kemudian disusul oleh ranah pengetahuan dan keterampilan.

Sikap spiritual merupakan sikap warga negara yang berkaitan dengan keyakinan, kepercayaan dan keimanan terhadap Tuhan Yang Maha Esa. Sikap sosial merupakan sikap warga negara satu dengan warga negara yang lain dalam kehidupan bermasyarakat, berbangsa dan bernegara. Apek pengetahuan berisikan pengetahuan kerwarganegaraan mencakup bidang politik, hukum, dan moral. Sedangkan aspek keterampilan adalah kemampuan dan kecakapan mengartikulasikan keterampilan kewargaan seperti kemampuan berpartisipasi dalam kehidupan sehari-hari.

Dalam buku teks PPKn SMP kurikulum 2013 dapat dilihat bahwa muatan civic disposition yang dominan dan kurang mengembangkan aspek pengetahuan (civic knowledge) dan keterampilan (civic skill). Hal yang sama dikemukakan oleh Muchson AR yang mengatakan bahwa "Buku teks PPKn kurikulum 2013 diakui memang memiliki muatan keilmuan kewarganegaraan yang kurang, justru penekanannya lebih pada kompetensi spiritual dan sosial, dan itu diakui oleh penulis buku", (Hasil wawancara pada hari Kamis, 8 Mei 2014). Cholisin juga mengatakan:

Buku kurikulum 2013, bahan ajarnya seharusnya menyediakan informasi sebanyak mungkin, karena siswa akan aktif mencari tapi lihat buku-buku ajarnya sangat miskin informasi, padahal buku itu menjadi bahan utama. Hal ini perlu untuk dipikirkan, (Hasil wawancara pada hari Rabu, 14 Mei 2014).

Secara keseluruhan muatan materi buku teks PKn kurikulum 2013 ini dapat disimpulkan bahwa kebijakan politik pendidikan lebih mengarah pada pembentukan manusia Indonesia yang beriman dan afektif (sikap spiritual dan sikap sosial), produktif, kreatif, inovatif (aspek pengetahuan), serta mampu berkontribusi pada kehidupan bermasyarakat, berbangsa, bernegara, dan peradaban dunia (aspek keteramilan).

\section{SIMPULAN}

PKn sebagai instrumen politik pendidikan dalam membentuk good citizens, dilihat dari muatan buku teks PKn (BSE) Kurikulum 2006 dan Kurikulum 2013, secara singkat dapat disimpulkan sebagai berikut :

Pertama, muatan buku PKn Kurikulum KTSP 2006 merupakan penyempurnaan dari Kurikulum KBK 2004. Buku ini berisikan kajian yang bersifat interdisipliner yang terdiri dari politik, hukum dan moral. Materi meliputi: Norma-Norma yang Berlaku dalam Kehidupan Bermasyarakat, Berbangsa dan Bernegara; Makna Proklamasi Kemerdekaan dan Konstitusi Pertama; serta Kemerdekaan Mengemukakan Pendapat. Dari keempat materi tersebut arah politik pendidikan pada masa ini lebih diarahkan kepada pembentukan warga negara yang warga negara yang cerdas, terampil dan berkarakter, sadar akan hak dan kewa jiban, serta mampu berpartisipasi aktif dalam kehidupan bermasyarakat, berbangsa dan bernegara.

Kedua, materi dalam buku teks PPKn Kurikulum 2013 meliputi: Beriman dan Bertakwa Kepada Tuhan Yang Maha Esa, Berkomitmen terhadap Pancasila sebagai Dasar Negara, Menumbuhkan Kesadaran Berkonstitusi, Menumbuhkan Kesadaran dan Keterikatan terhadap Norma, Memaknai Nilai Kesejarahan NKRI, Pentingnya Daerah dalam Bingkai 
NKRI, Memelihara Semangat Persatuan Indonesia, dan Bertoleransi dalam Keberagaman. Arah politik pendidikan sebagaimana tercantum dalam Permendikbud No.63 tahun 2013 tentang Kerangka Dasar dan Struktur Kurikulum Sekolah Menengah Pertama/ Madrasah Tsanawiyah, yaitu untuk mempersiapkan manusia Indonesia agar memiliki kemampuan hidup sebagai pribadi dan warga negara yang beriman, produktif, kreatif, inovatif, dan afektif serta mampu berkontribusi pada kehidupan bermasyarakat, berbangsa, bernegara, dan peradaban dunia. Oleh karena itu materi di dalam buku Kurikulum 2013 ini mengarah pada pengembangan aspek sikap (sikap spiritual dan sikap sosial), aspek pengetahuan dan aspek keterampilan. Sikap spiritual di pelajari pertama kali karena negara ingin membentuk karakter warga negara yang religius, mampu bersikap dan bertindak senantiasa berdasarkan ajaran agama yang dianut. Ranah kedua adalah sikap sosial. Ranah ini digambarkan melalui manusia sebagai makhluk sosial yang selalu beriteraksi dengan manusia lain. Sikap sosial dibentuk melalui pemahaman terhadap materi yang bersifat pengembangan aspek kognitif. Ranah keterampilan merupakan ranah di mana siswa mempraktekkan materi yang telah dipelajari melalui pengerjaan tugas-tugas dan latihan soal.

Muatan civic knowlegde, civic skill dan civic disposition di dalam buku teks PKn berbeda di setiap kurikulumnya, secara singkat sebagai berikut:

Pertama, secara keseluruhan dalam buku PKn Kurikulum KTSP 2006 sarat akan muatan politik dan hukum, sedangkan aspek nilai moral khususnya nilai moral Pancasila kurang mendapat porsi. Hal ini menunjukkan bahwa kebijakan politik dibidang kurikulum era Reforamasi berusaha untuk membentuk warga negara yang tidak hanya bermoral (menekankan pada aspek values saja) tetapi juga aspek membentuk warga Negara yang cerdas (civic knowledge), dan terampil (civic skill).

Pengetahuan moral (moral knowing) meliputi pengetahuan terhadap norma hu- kum dan peraturan, makna proklamasi kemerdekaan, HAM dan kemerdekaan mengemukakan pendapat. Perasaan moral (moralfeeling) yang meliputi pentingnya norma, suasana kebatinana konstitusi UUD 1945, menghargai harkat dan martabat manusia, serta menghargai kemerdekaan mengemukakan pendapat secara bebas dan bertangung jawab. Tindakan moral (moral action) meliputi penerapan norma hukum dan peraturan dalam kehidupan nyata, melaksanakan konstitusi sebagai dasar hukum negara, turut serta dalam upaya perlindungan dan penegakan HAM, serta berpartisipasi dalam mengemukakan pendapat secara bebas dan bertanggung jawab.

Kedua, dalam buku PPKn Kurikulum 2013, muatan civic disposition lebih dominan sehingga kurang mengembangkan aspek pengetahuan (civic knowledge) dan keterampilan (civic skill). Berdasarkan tema-tema yang dimuat dalam buku PPKn ini, dapat dilihat bahwa tema-tema tersebut seperti kembali pada kurikulum 1994 Suplemen 1999 yang sarat akan nilai moral (terutama Pancasila) dan miskin pengetahuan, yang membedakan adalah pada buku PPKn kurikulum 2013 ini, siswa dilatih untuk lebih aktif dan partisipatif melalui berbagai jenis latihan soal. Melalui latihan soal ini pula siswa dapat memperkaya pengetahuan (knowledge) sekaligus mengasah keterampilan (skill) mereka sendiri melalui temuan-temuan langsung (self discovery).

\section{UCAPAN TERIMA KASIH}

Kami ucapkan terima kasih kepada pihak-pihak yang telah membantu kami dalam proses pengambilan data di lapangan maupun pihak yang telah membantu dalam memudahkan transportasi kami. Selanjutnya terima kasih kepada redaksi jurnal yang mempublikasikan artikel hasil penelitian ini sehingga dapat dibaca oleh mahasiswa, guru dan masyarakat luas. Semoga hasil pnelitian ini bermanfaat untuk kehidupan akademik dan sosial selanjutnya.

\section{DAFTAR PUSTAKA}

Banks, James. (2008). Diversity, group identity, and citizenship education in global age. 
Educational Researcher, Vol. 30, No. 3, p. 136-137.

Burhan, Bungin. (2008). Analisis data penelitian kualitatif : pemahaman filosofis dan metodologis kearah penguasaan model aplikasi. Jakarta: Raja Grafindo Persada.

Branson. (1999). Belajar civic education dari Amerika. (Terjemahan Syarifudin, dkk) Yogyakarta: Lembaga Kajian Islam dan Sosial (LKIS) dan The Asia Foundation (TAF).

Freire, Paulo. (2007). Politik pendidikan (kebudayaan, kekuasaan dan pembebasan). Yogyakarta: Pustaka Pelajar.

Krippendorf, Klaus. (1981). Content analysis an introduction to its methodology. London: SAGE Publication.

Lickona, Thomas. (1991). Educating for character. how our school can teach respect and responsibility. New York: Bantam Books.

Murdiono, Mukhamad. (2012). Strategi pembelajarn kewarganegaraan berbasis portofolio. Yogyakarta: Penerbit Ombak.

Peraturan Menteri Pendidikan Nasional No.11 tahun 2005 tentang Buku Teks Pelajaran. Peraturan Pemerintah No. 19 tahun 2005 tentang Standar Nasional Pendidikan.

Peraturan Menteri Pendidikan Nasional No. 22 tahun 2006 tentang Standar Isi.

Sapriya.(2007).Peranpendidikankewarganegaraan dalam membangun karakter warga negara. Jurnal Sekolah Dasar, vol.16 no.1 Mei.

Sugiyono. (2007). Metodologi penelitian pendidikan. Bandung : Alfabeta

Sukardi. (2008). Metodologi penelitian pendidikan kompetensi dan praktiknya. Jakarta: Bumi Aksara.

Tilaar, H.A.R. (2002). Penidikan untuk masyarakat indonesia baru. Jakarta: Grasindo.

Undang-Undang Dasar Negara Republik Indonesia tahun 1945.

Undang-Undang No. 20 tahun 2003 tentang Sistem Pendidikan Nasional.

Zamroni. (2011). Pendidikan demokrasi pada masyarakat multikultural. Yogyakarta: Gavin Kalam Utama. 